\title{
Two More of Our Advisory Editors Share the (1993) Volvo Environment Prize
}

Fol of llowing its award last year (shared with the Director of the Missouri Botanical Garden) to our Advisory Editor and frequent contributor, Dr Norman Myers, the 1993 Volvo Environment Prize is being bestowed on two more of our Advisory Editors - both Pennsylvania-born but occupying named Chairs at leading Universities in California. They are Professors Paul R. Ehrlich, of Stanford University, and John P. Holdren, of the University of California at Berkeley, who are cited 'for their pioneering work on the relationship between population growth, resource consumption, and the Earth's carrying capacities.'

A celebrated evolutionary biologist who, with such books as The Population Bomb to his credit, has long been in the forefront of those warning about the dangers of human overpopulation, Paul Ehrlich is 61 years of age and currently Bing Professor of Population Studies in the Department of Biological Sciences at Stanford University.

John Holdren is a younger man, still not yet 50, who holds the Class of ' 35 Professorship of Energy \& Resources in the University of California at Berkeley, and who 'was the principal architect and builder of the Energy and Resources Group (ERG), a unique, interdisciplinary graduate degree-program addressing problems of energy, resources, development, and environment, by integrating methods and insights from a wide range of natural and social science disciplines. ERG is recognized today as one of the best academic science-and-policy programs in the world.' (quoted from Volvo Press Information).

Both Ehrlich and Holdren are members of the US National Academy of Sciences and Fellows of the American Academy of Arts and Sciences, and both have received MacArthur Prize Fellowships. According to the

same source, they were honoured 'for their outstanding and pioneering contributions to our understanding of the threats to human development and survival, particularly those arising from the rapid growth of populations in developing countries and the high level of [per caput] resources consumption in industrialized countries.'

The Prize Committee recorded that 'their early work and reports* have laid the Foundation for our understanding of the dramatic nature and relative roles of population growth, rising affluence and changing technology in the environmental problematique. Their work on the interactive linkages between population, resource-use, and technology, has served to highlight issues of international security, ranging from the nuclear arms race to potential conflicts over resources.'

Commenting on the awards, the Chairman of the Prize Committee, Dr Mostafa K. Tolba, until recently Executive Director of the United Nations Environment Programme (UNEP), said 'In almost 20 years at UNEP I have met and worked with hundreds of scientists, but none of them has been more committed to the environmental cause than Ehrlich and Holdren. They are highly original thinkers who have had a real influence on their colleagues, on environmental organizations, [and on] governments and public opinion.'

This to us represents a fresh case - in some senses two cases - of where important work is being facilitated and surely enhanced by substantial pecuniary awards such as are still all-too-rare in the hard-pressed environmental movement.

\section{Nicholas Polunin}

* In some notable cases together, with or without Paul Ehrlich's able wife Anne. - Ed.

\section{Oil-spill Endangers Island Wildlife}

$\mathrm{T}$ he well-known, largest nesting populations of the better-known sea-turtles - the Leatherback Turtle (Dermochelys coriacea) and the Hawksbill Turtle (Eretmochelys imbricata) - which find refuge in the Andaman and Nicobar Islands off the Indian subcontinent, are threatened by predatory activities of Mankind. Until the 1970s, the populations of these sea-turtle species provided a very significant nucleus to the world pool (Bhaskar \& Andrews, 1993). Even the Dugong or Seacow (Dugong dugon), economically important, has only vulnerable numbers surviving around the Andaman Islands, due to overexploitation.

However, the latest oil-spill and resultant slick, from the Danish oil-tanker which collided with a Japanese vessel, poses still more dangers to those creatures' habitat; consequently, populations of the turtles may be expected to decline drastically, as they are unable to adapt themselves to more restricted or otherwise changing habitats. We may have to identify their population as 'on their way out'.

Moreover, the coastal marshy areas which harbour concentrations of mangrove and other special vegetation, dominated by species of Avicennia, Bruguiera, Ceriops, Rhizophora, and Sonneratia as well as by the Nypa palm and Pandanus species, are likely to be adversely affected and even run the risk of decimation.

\section{Particular Vulnerability of Oceanic Islands}

Oceanic Islands are all-too-vulnerable, due to the destruction of their habitats commonly through human predation. Much remains to be done, in the context of serious oil-pollution in the Indian Ocean, to extend a new lease of life to the marine turtles for years to come.

The Author had earlier put in a plea to have the Indian Ocean declared a Zone of Peace for Nature - in the 18th General Assembly of IUCN, held in Perth, Western Australia, and also at the International Environmental Law Conference held at the Hague, The Netherlands (Oza, 1991).

Oceanic Islands comprise some of the worst dangerspots. A sense of urgency is needed among people who would save some of their precious wildlife heritage before it has passed the point of no return. The Indian Ocean and the many Oceanic Islands shelter interesting and often unique wildlife.

If our heritage is not steadily and increasingly to be whittled away, emergency measures must be put into genuine action at the earliest possible time - to declare and set aside particular islands as sanctuary areas, and to curb, by all possible means, illegal and indiscriminate predatory visits by ships and disruptive military exercises. Such a safeguard is vital to halt the final extirpation of island habitats and wildlife. 
The Author puts his earnest plea again before the world powers to leave the Indian Ocean as a Zone of Peace for Nature - in order to preserve its wildlife and maintain the ecological balance of the area for conservation.

This should give support to the International Whaling Commission (IWC) to have the Indian Ocean set aside as a Whale Sanctuary - to protect not only the populations of great whales but also the smaller cetaceans, notably dolphins and porpoises (Oza, 1983).

\section{Institutional Change Needed to Deal with Environmental Threats}

The Hague Recommendations on International Environmental Law were adopted for consideration by UNCED at Rio and other appropriate international fora. Basic principles for the preservation of the environment and their enforcement need to be guaranteed at a global level. The main framework available today is the UN system, which States have failed to use and develop adequately to stop further deterioration of the global environment and its essential features.

At present, the UN system is not adequately equipped for this task. Therefore, in order to reach this goal, either the UN system has to be changed or a new body has to be established.
If the enhancement of UNEP, as referred to above, proves not to be feasible, a World Environmental Authority should be established to oversee and integrate international environmental efforts, and to deal with urgent problems affecting the environment of our 'only one Earth' (Oza, 1991).

\section{REFERENCES}

Bhaskar, Satish \& Andrews, Harry (1993). Action Plan for Sea Turtles in the Andaman and Nicobar Islands, India. Marine Turtle Newsletter, 60, p. 23.

OzA, G.M. (1983). An Indian view of Man and Nature. Environmental Conservation, 10(4), pp. 331-5.

OzA, G.M. (1991). Conference on International Environmental Law, held in the Peace Palace, The Hague, The Netherlands, during 12-16 August 1991. Environmental Conservation, 18(4), pp. 374-6.
Gunavant M. Oza
Department of Botany, Faculty of Science,
The Maharaja Sayajirao University of Baroda
Baroda 390002, India; General Secretary
of the International Society of
Naturalists (INSONA)
$\&$ the Founding Editor of Environmental Awareness,
Oza Building,
Salatwada, Baroda 390001, India.

\section{The Biodiversity* Treaty}

$\mathrm{O}_{\mathrm{s}}^{\mathrm{n}}$ n 30 September 1993, Mongolia had the distinction of being the 30th country to ratify the treaty on biological diversity*, triggering the 90 -days countdown to the Treaty's entry into force. On 29 December 1993 the treaty will become a binding legal instrument, taking its place in international law.

'I congratulate the 30 countries whose recognition of the urgency of this Convention led to early ratification, propelling the world forward on this most important agenda', said Elizabeth Dowdeswell, Executive Director of the United Nations Environment Programme. 'I especially appreciate the leadership of small island states, a dozen of whom are among this signal group, and the many countries which are pressing ahead to develop action plans for the conservation of biological diversity.'

The treaty has three objectives: (1) conservation of biological diversity; (2) sustainable use of its components (plants, animals, and microorganisms), and (3) fair and equitable sharing of the benefits that result from the use of genetic resources.

'We must reverse the tide of the devastating loss of the Earth's living resources', said Miss Dowdeswell. 'In the year 2093, I hope and imagine that our great-grandchildren will look out on a world even richer in biological diversity than ours is now, and trace it back to this date. It is our generation, which must act, now and with great energy, if we are to preserve the resources which hold the

\footnotetext{
* It is most important to note that, in the words of the communication specialist of the Interim Secretariat, Biodiversity or 'biological diversity is an umbrella term for Nature's variety ecosystems, species, and genes.' - Ed.
}

key to future survival.'

While planet Earth is the home to an estimated 10 million species, only 1.5 million of them have been identified to date. No one knows what unidentified species might offer in terms of food, clothing, housing, or medicine - just to mention a few areas of our lives that are affected on a daily basis by biological diversity. This vast reservoir of genetic resources is also the source of the oxygen we breathe, many of our industries, and, perhaps most significantly, our ability to adapt to changing circumstances such as global warming.

The 30th ratification comes on the eve of the first major intergovernmental meeting on the biodiversity treaty since Rio. It will take place in Geneva during 11-15 October. This will prepare the way for the Conference of the Parties - all countries which have ratified - to meet for the first time next year.

In chronological order the following countries were the first 30 to ratify the biological diversity treaty: Mauritius, Seychelles, Marshall Islands, Maldives, Monaco, Canada, China, Saint Kitts \& Nevis, Ecuador, Fiji, Antigua \& Barbuda, Mexico, Papua New Guinea, Vanuatu, Cook Islands, Guinea, Armenia, Japan, Zambia, Peru, Australia, Norway, Tunisia, Saint Lucia, Bahamas, Burkina Faso, Belarus, Uganda, New Zealand and now Mongolia.

Convention on Biological Diversity Interim Secretariat 15 Chemin des Anémones CP 356 CH-1219 Châtelaine Geneva, Switzerland. 